\title{
Influence of Farmer demographics and Supply Chain Issues on Organized Retailer Performance
}

\author{
Aruna Prabhu ${ }^{*}$, B. Giridhar Kamath ${ }^{2}$, A. Karthik ${ }^{1}$ and Kushagra Sinha ${ }^{1}$ \\ ${ }^{1}$ Department of Mechanical and Manufacturing Engineering, Manipal Institute of Technology, \\ Manipal Academy of Higher Education, Manipal, India \\ ${ }^{2}$ Department of Humanities and Management, Manipal Institute of Technology, Manipal Academy of \\ Higher Education, Manipal, India
}

\begin{abstract}
Advances in information technology and increased social networking have increased health awareness among people in this era. The increased health awareness has prompted people to eat healthy and stay fit. In this regard, the food sector has seen tremendous demand in terms of good quality vegetables/fruits, cereals, with hygiene, nutrition, proteins etc. With the consumer willing to pay an extra premium for the quality expected, it has been observed that the producers are still offered low prices for a good quality produce whereas the intermediaries grab a huge share of the price paid by the consumer. This research tried to understand the supply chain with the farmers in focus and explored the influence of farmer demographics and the supply chain issues on the performance of the organized retail. Linear regression analysis was used to test the linear relationship of supply chain issues with organized retailer performance. The outcome of the study implies that independent variables like demographic characteristics and supply chain issues had no control over the retailer's performance.
\end{abstract}

Keywords: Supply chain issues, Demographic factors, Statistical analysis, Organized retailer performance

\section{Introduction}

In terms of production of fruits and vegetables, India is in the second place after china [1]. In India, fruits and vegetables $(\mathrm{F} \& \mathrm{~V})$ is a fast growing sector and comprises around 90 per cent of the total horticulture produce. It is believed that, in future the F\&V segment has high potential to drive agricultural growth with the rising demand for these commodities. The F\&V plays a vital role in improving the income of farming community, generating employment opportunities and thereby contributing to India's economy.

India is considered to be most suitable for farming various types of fruits and vegetables due to the condition of soil, climate change and geography [1]. Numerous aspects such as growing population, changing life styles, nuclear families, working women, increasing urbanization are favourably influencing the food supply chains hinting at a better future.

\footnotetext{
* Corresponding author: aruna.prabhu@manipal.edu
} 
However, increasing health awareness has influenced the food consumption pattern with a transition from the consumption of food grain to fruit and vegetables. This has increased the demand for protein rich, high value nutritional food. Perishability and very short shelf life of fruit and vegetables need a proper supply chain to make sure that the produce is still fresh when it reaches the customer. Wastage is a major issue threatening the Fruit and Vegetable sector. Fruit and Vegetable sector accounts for about 2 lakh crore Rupees worth wastage every year due to the lack of proper cold chain infrastructure [2] [3].

Demand for fresh fruits and vegetables is gradually increasing with rising population. However, the shelf life of these is a concern. Increase in demand for the processed food has created various opportunities in production, supply chain and marketing of agricultural commodities. This has attracted attention of several players in the industry and the last few years particularly has seen several private food retail players in India entering the food processing and supply chain sector with huge investments as they expect attractive growth opportunities in the future [4]. To facilitate the development of this sector, the government of India has initiated different schemes and incorporated policy changes at different levels. Various researchers have highlighted the pathetic conditions of current agri-food supply chains, and also pointed out the various issues, challenges and opportunities in the sector. In an attempt to address this issue, this study will focus on the following objectives:

1. To analyse the influence of farmer demographics on organized retailer performance.

2. To identify the supply chain issues and its impact on organized retailer performance.

\section{Literature review}

\subsection{Supply chain in fruits and vegetables sector in India}

The supply chain management is to ensure that the product is reached to the proper destination at exact time by optimizing the existing inventory [5]. Supply chain management (SCM) is also defined as "a well-established of practices employed to efficiently integrate all stake holders like vendors, retailers, producers, and stores, thus the goods are created and circulated to the right places, at the right cost and at the right time, so as to reduce total costs while fulfilling service level necessities". The supply chain management concepts are widely used in manufacturing and service fields, but not applied in the agriculture sector even though the agriculture commodities are the raw materials for most of the industries and also major part of world economy. In some papers, the supply chain management of agri-fresh produce is referred as agri-fresh supply chain management (FSCM), comprises all the process involved from the production to the delivery of agrifresh produce. FSCM is complicated when compared with other SCMs because it carries items which are perishable in nature, short shelf life, demand and price fluctuations, dependence on climate conditions, and consumer concerns for food safety [6]. The existing supply chains in F\&V sector consists of lot of intermediaries who grab about 75 per cent of the total net margin accumulated throughout the supply chain [7]. The agri-fresh produce has to cross about six to seven different distribution channels from farmer to consumer [8]. The F\&V supply chain carries number of intermediaries who perform various tasks such as transportation, maintenance and preservation of quantity and quality, transfer of ownership of commodities, payment to the seller and delivering commodity to the buyer [4].

\subsection{Value chain model in fruits and vegetables supply chain}

Famers, organized retailers and customers are the players in this supply chain model. Reliance Retail Ltd is following a value chain model and purpose of this model is to buy 
agri-produce directly from the farmers and sell it to customers thereby avoiding intermediaries. The agri-produce movement takes place from farmer or contract farmer or lease famers to wholesaler hubs through agents or consolidation centres, wholesaler's hubs to small stores, and then small stores to customers. Organized retailers receive the agriproduce directly from small farmers, contract farmers and lease farmers. Contract farmers and lease farmers supply agri-produce on sale trade agreement with the retailer. The Value chain model is as shown in Fig. 1.

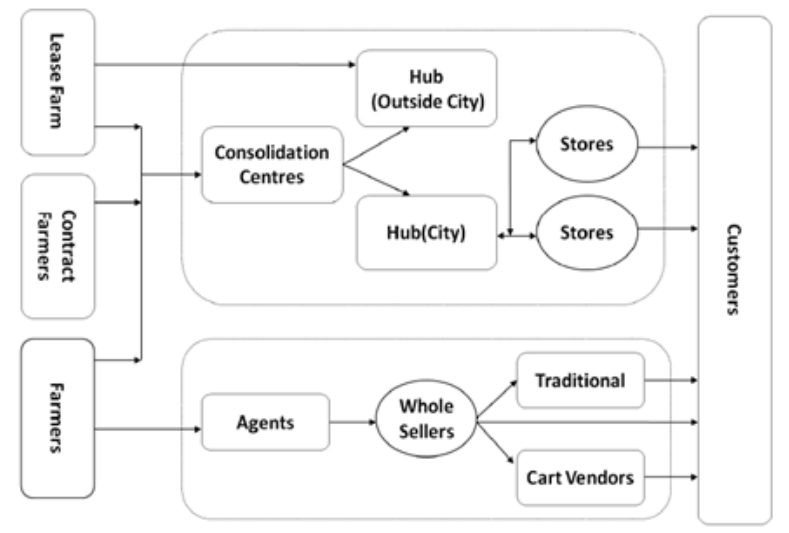

Fig. 1. Value chain model (Source: Halder and Pati, 2012)

Initially, farmers send their vegetables to the consolidation centres based on the trade agreements. Then these vegetables are transported to hubs and quality and are well maintained with a proper cold chain. Depending upon the requirements, vegetables are transported from hub to stores twice a day in a fresh state. Customers visit to the nearest retail stores to purchase the fresh vegetables [3] [4].

\subsection{Issues in fresh fruits and vegetables supply chain}

Fruits and vegetable supply chain need a proper infrastructure from farm level to consumer. Various researchers have identified several issues in this supply chain. Some of these are: lack of a proper infrastructure for maintaining agri-produce in fresh state i.e. cold chain, poor transportation facilities; small farmers are fragmented type and can only produce less quantity of agri-produce and cannot afford latest technologies; difficulty in integrating the stakeholders; and, uneducated farmers are unaware of demand or market information. These farmers cannot incorporate technologies for quality processed and packaged food which is in demand now days. Farmers also have lack of knowledge about post-harvest losses [1]. Wastages in Indian fruits and vegetables supply chain takes place mainly due to lack of cold storage, poor logistics, and unscientific harvesting/processing methods, lack of communication and coordination, inappropriate demand information and lot of intermediaries in supply chain[9]. Age, gender, marital status, education level, field experience, earnings are important variables that influence the work place performance of an employee [10]. Factors influencing the fruits and vegetable supply chain in India are population and demographic changes, integration in Agri-sector, emergence of organized retail, emergence of technologies, globalization, and government role [11]. 


\subsection{Organized Retailer Performance}

Organized retailers performance is measured in four important dimensions such as financial, operational, environmental and social performance. Sales growth, increase in market share and profit are relating to economic outcomes. Efficiency, productivity, inventory level, \& optimum utilization of capacity reflect operational performance. Reduced emissions and pollution, savings in power consumptions are linked to environmental performance. Similarly organizations people friendly initiatives and practices like employee morale, company image, and community relations are treated as social performance [12] [13].

\section{Research Methodology}

The main purpose of this research was to study the impact of supply chain factors on organized retailer performance. A detailed qualitative investigation was conducted in the area of agri-supply chain management. Journal papers related to the field of agri-supply chain were surveyed to identify the factors influencing vegetable supply chain and organized retailer performance. Questionnaire was designed based on the prior studies in the field of agricultural supply chain. Factors influencing the supply chain were identified and questions were framed to obtain answers to research objectives. A questionnaire is used as measuring instrument which was developed after the completion of literature survey [14]. The data collection was done with closed-ended, structured questionnaire from various farmers of Udupi district, India. Questionnaires were served to the farmers who supply their vegetables to organized retailers like Bigbazar, More, Neelgiries and Super Bazar etc. Educated farmers were asked to fill the questionnaire and uneducated farmers were interviewed to obtain the accurate responses. In this survey, 87 completely filled questionnaires were collected.

\subsection{Population and Sampling}

Our study was focused on vegetable supplying farmers to organized retailers so the size of population was estimated to be 120 farmers. This population size of farmers was decided approximately based on the feedback obtained from various vegetable vendors of district. Following formula can be used to calculate the sample size (n) is given by: [15].

$$
\begin{aligned}
\mathrm{n} & =\mathrm{N} /\left(1+\mathrm{Ne}^{2}\right) \\
& =93 \text { samples } \\
\text { where, } \mathrm{N} & =120 \text { persons and } \\
\mathrm{e} & =0.05 \text { (is desired level of precision). }
\end{aligned}
$$

\subsection{Hypotheses}

Following hypotheses are framed based on the literature studies, $\mathrm{H}_{1}$ : Demographic factors are influencing organized retailer performance.

$\mathrm{H}_{2}$ : Supply chain issues are related to organized retailer performance. 


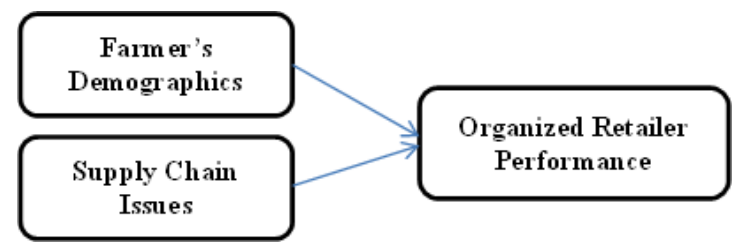

Fig. 2. Conceptual framework (Source: Authors)

Conceptual framework is developed based on the literature study. Organized retailer performance is dependent variable which is influenced by two independent variables demographic characteristics and supply chain issues.

\section{Data analysis}

Table 1. Frequency table

\begin{tabular}{|c|c|c|c|}
\hline Variable & Groups & Frequency & Percent \\
\hline \multirow{2}{*}{ Gender } & Male & 68 & 78.2 \\
\hline & Female & 19 & 21.8 \\
\hline \multirow{4}{*}{ Age } & $20-30$ years & 02 & 2.3 \\
\hline & $31-40$ years & 08 & 9.2 \\
\hline & $41-50$ years & 26 & 29.9 \\
\hline & Above 50 years & 51 & 58.6 \\
\hline \multirow{2}{*}{ Marital Status } & Unmarried & 08 & 9.2 \\
\hline & Married & 79 & 90.8 \\
\hline \multirow{4}{*}{ Education Level } & Illiterate & 27 & 31 \\
\hline & Primary School & 46 & 52.9 \\
\hline & High school & 12 & 13.8 \\
\hline & Above PU & 02 & 2.3 \\
\hline \multirow{4}{*}{ Field Experience } & lessthan 5 years & 02 & 2.3 \\
\hline & $5-10$ years & 03 & 3.4 \\
\hline & 10-15 years & 09 & 10.3 \\
\hline & Above 15 years & 73 & 83.9 \\
\hline \multirow{4}{*}{$\begin{array}{c}\text { Income Level (in } \\
\text { Rupees) }\end{array}$} & lessthan $1 \mathrm{Lakh}$ & 29 & 33.3 \\
\hline & 1 to 3 Lakhs & 49 & 56.3 \\
\hline & 3 to 5 Lakhs & 09 & 10.3 \\
\hline & Above 5 Lakhs & 00 & 00 \\
\hline
\end{tabular}

Statistical Package for the Social Science (SPSS) software was used to analyse the data collected from the survey. The information from each questionnaire was entered and coded carefully in SPSS software prior to the analysis. Demographics of data collection are highlighted in the table 1. From the above table, the maximum number of samples in gender variable are male respondents i.e.68\%; the maximum number of samples of age variable is above 50 years old is $58.6 \%$; Married people respondent is highest in marital status variable i.e.91\%; respondents with primary school education level is highest i.e. $52.9 \%$ followed by illiterate i.e. $31 \% ; 83.4 \%$ of respondents are with field experience more than 15 years; $56.3 \%$ of respondents are with an income level in rupees between 1 lakh to 3 lakhs is highest followed by $33.3 \%$ of respondents with less than 1lakh income. 


\subsection{Hypotheses testing results}

\subsubsection{The analyses of influence of demographic factors on organized retailer performance}

$A$. The results of organized retailer performance is influenced by demographic variable farmer's gender

Independent sample t-test is used for testing the hypothesis 1.1

Hypothesis 1.1

$\mathrm{H}_{0}$ 1.1.1: Farmer's gender doesn't influence organized retailer performance.

$\mathrm{H}_{\mathrm{a}}$ 1.1.2: Farmer's gender influence organized retailer performance.

The study result indicates that test t-value is 1.018 and significance value i.e. $p$-value is 0.316 . As the significance value is greater than 0.05 , it is unable to reject null hypothesis at $5 \%$ significance level.

Table 2. The analyses of influence of demographic factors on organized retailer performance

\begin{tabular}{|c|c|c|c|c|c|}
\hline \multicolumn{6}{|c|}{$\begin{array}{c}\text { A. The results of organized retailer performance is influenced by farmer's gender - } \\
\text { Independent Sample t-Test }\end{array}$} \\
\hline Variable & Gender & Mean & Standard Deviation (S.D) & Statistics & $\begin{array}{l}\text { Significance } \\
\text { Value }\end{array}$ \\
\hline \multirow{2}{*}{$\begin{array}{c}\text { Organized } \\
\text { Retailer } \\
\text { Performance }\end{array}$} & Male & 23.83 & 2.86 & \multirow{2}{*}{1.018} & \multirow{2}{*}{0.316} \\
\hline & Female & 22.10 & 3.12 & & \\
\hline \multicolumn{6}{|c|}{$\begin{array}{c}\text { B. The results of organized retailer performance is influenced by farmer's age- One Way } \\
\text { Annova Test }\end{array}$} \\
\hline Variable & Age & Mean & Standard Deviation (S.D) & Statistics & $\begin{array}{l}\text { Significance } \\
\text { Value }\end{array}$ \\
\hline \multirow{4}{*}{$\begin{array}{l}\text { Organized } \\
\text { Retailer } \\
\text { Performance }\end{array}$} & $20-30$ & 27 & 1.41 & \multirow{4}{*}{1.891} & \multirow{4}{*}{0.137} \\
\hline & $31-40$ & 24.75 & 2.65 & & \\
\hline & $41-50$ & 23.65 & 3.02 & & \\
\hline & above 50 & 23.45 & 2.96 & & \\
\hline \multicolumn{6}{|c|}{$\begin{array}{c}\text { C. The results of organized retailer performance is influenced by farmer's marital status - } \\
\text { Independent Sample t-Test }\end{array}$} \\
\hline Variable & Marital Status & Mean & Standard Deviation (S.D) & Statistics & $\begin{array}{c}\text { Significance } \\
\text { Value }\end{array}$ \\
\hline \multirow{2}{*}{$\begin{array}{c}\text { Organized } \\
\text { Retailer } \\
\text { Performance }\end{array}$} & Unmarried & 25.5 & 2.61 & \multirow{2}{*}{1.276} & \multirow{2}{*}{0.262} \\
\hline & Married & 23.25 & 2.96 & & \\
\hline \multicolumn{6}{|c|}{$\begin{array}{c}\text { D. The results of organized retailer performance is influenced by farmer's level of education } \\
\text {-One Way Annova Test }\end{array}$} \\
\hline Variable & Education Level & Mean & Standard Deviation (S.D) & Statistics & $\begin{array}{c}\text { Significance } \\
\text { Value }\end{array}$ \\
\hline \multirow{4}{*}{$\begin{array}{l}\text { Organized } \\
\text { Retailer } \\
\text { Performance }\end{array}$} & Illiterate & 23.62 & 2.73 & \multirow{4}{*}{1.194} & \multirow{4}{*}{0.317} \\
\hline & Primary School & 23.13 & 3.09 & & \\
\hline & High School & 23.75 & 3.16 & & \\
\hline & PU and above & 27 & 1.41 & & \\
\hline \multicolumn{6}{|c|}{$\begin{array}{l}\text { E. The results of organized retailer performance is influenced by farmer's field experience - } \\
\text { One Way Annova Test }\end{array}$} \\
\hline Variable & $\begin{array}{c}\text { Field } \\
\text { Experience }\end{array}$ & Mean & Standard Deviation (S.D) & Statistics & $\begin{array}{l}\text { Significance } \\
\text { Value }\end{array}$ \\
\hline
\end{tabular}




\begin{tabular}{|c|c|c|c|c|c|}
\hline \multirow{4}{*}{$\begin{array}{l}\text { Organized } \\
\text { Retailer } \\
\text { Performance }\end{array}$} & $\begin{array}{l}\text { Less than } 5 \\
\text { Years }\end{array}$ & 27 & 1.41 & \multirow{4}{*}{1.082} & \multirow{4}{*}{0.361} \\
\hline & 5 to 10 Years & 24.33 & 2.51 & & \\
\hline & 10 to 15 Years & 23.55 & 3.46 & & \\
\hline & Above 15 Years & 23.31 & 2.95 & & \\
\hline \multicolumn{6}{|c|}{$\begin{array}{l}\text { F. The results of organized retailer performance is influenced by farmer's income - One } \\
\text { Way Annova Test }\end{array}$} \\
\hline Variable & $\begin{array}{l}\text { Income Level } \\
\text { (Rupees) }\end{array}$ & Mean & Standard Deviation (S.D) & Statistics & $\begin{array}{l}\text { Significance } \\
\text { Value }\end{array}$ \\
\hline \multirow{3}{*}{$\begin{array}{l}\text { Organized } \\
\text { Retailer } \\
\text { Performance }\end{array}$} & Up to 1 Lakh & 22.72 & 2.75 & \multirow{3}{*}{2.369} & \multirow{3}{*}{0.1} \\
\hline & 1 to 3 Lakhs & 23.59 & 3.08 & & \\
\hline & 3 to 5 Lakhs & 25.11 & 2.71 & & \\
\hline
\end{tabular}

Hence, gender variable does not influence organized retailer performance at 5\% significance level as described in table 2 .

B. The results of organized retailer performance is influenced by demographic variable farmer's age

One way Annova test is used for testing the hypothesis 1.2

Hypothesis 1.2

$\mathrm{H}_{0}$ 1.2.1: Farmer's age doesn't influence organized retailer performance.

$\mathrm{H}_{\mathrm{a}}$ 1.2.2: Farmer's age influences organized retailer performance.

The study result indicates that test F-value is 1.891 and significance value i.e. p-value is 0.137 . As the significance value is greater than 0.05 , it is unable to reject null hypothesis at $5 \%$ significance level. Hence, age variable does not influence organized retailer performance at 5\% significance level as described in table 2 .

C. The results of organized retailer performance is influenced by demographic variable farmer's marital status

Independent sample t-test is used for testing the hypothesis 1.3

Hypothesis 1.3

$\mathrm{H}_{0}$ 1.3.1: Farmer's marital status doesn't influence organized retailer performance.

$\mathrm{H}_{\mathrm{a}}$ 1.3.2: Farmer's marital status influences organized retailer performance.

The study result indicates that test t-value is 1.276 and significance value i.e. p-value is 0.262 . As the significance value is greater than 0.05 , it is unable to reject null hypothesis at $5 \%$ significance level. Hence, marital status variable does not influence organized retailer performance at $5 \%$ significance level as described in table 2 .

D. The results of organized retailer performance is influenced by demographic variable farmer's education level

One way Annova test is used for testing the hypothesis 1.4

Hypothesis 1.4

$\mathrm{H}_{0}$ 1.4.1: Farmer's education level doesn't influence organized retailer performance.

$\mathrm{H}_{\mathrm{a}}$ 1.4.2: Farmer's education level influences organized retailer performance.

The study results indicate that test F-value is 1.194 and significance value i.e. p-value is 0.317 . As the significance value is greater than 0.05 , it is unable to reject null hypothesis at $5 \%$ significance level. Hence, education level variable does not influence organized retailer performance at $5 \%$ significance level as described in table 2 . 
E. The results of organized retailer performance is influenced by demographic farmer's field experience

One way Annova test is used for testing the hypothesis 1.5

Hypothesis 1.5

$\mathrm{H}_{0}$ 1.5.1: Farmer's field experience doesn't influence organized retailer performance.

$\mathrm{H}_{\mathrm{a}}$ 1.5.2: Farmer's field experience influences organized retailer performance.

The study result indicates that test F-value is 1.082 and significance value i.e. $p$-value is 0.361 . As the significance value is greater than 0.05 , it is unable to reject null hypothesis at $5 \%$ significance level. Hence, farmer's field experience variable does not influence organized retailer performance at $5 \%$ significance level as described in table 2 .

F. The results of organized retailer performance is influenced by demographic variable Farmer's income level

One way Annova test is used for testing the hypothesis 1.6

Hypothesis 1.6

$\mathrm{H}_{0}$ 1.6.1: Farmer's income level doesn't influence organized retailer performance.

$\mathrm{H}_{\mathrm{a}}$ 1.6.2: Farmer's income level influences organized retailer performance.

The study result indicates that test F-value is 2.369 and significance value i.e. p-value is 0.1 . As the significance value is greater than 0.05 , it is unable to reject null hypothesis at $5 \%$ significance level. Hence, farmer's income level variable does not influence organized retailer performance at $5 \%$ significance level as described in table 2 .

G. Summary of influence of demographic factors on organized retailer performance

The statistical analysis is conducted with a significance level 5\% and the results reveal that none of demographic factor stated in the study influence organized retailer performance. So this concludes that farmer's demographic factors not to be considered for measuring the supply chain performance of the organised retailer.

\subsubsection{Results of supply chain issues are related to organized retailer performance.}

Linear regression analysis is used for testing the hypothesis 2.1

Hypothesis 2.1

$\mathrm{H}_{0}$ 2.1.1: Supply chain issues are not related to organized retailer performance.

$\mathrm{H}_{\mathrm{a}} 2$.1.2: Supply chain issues are related to organized retailer performance.

Regression analysis is performed to find the linear relationship between variables supply chain issues and organized retailer performance.

Table 3. Regression analysis-model summary

\begin{tabular}{|c|c|}
\hline Dependent variable & Organized Retailer Performance (Y) \\
\hline Independent Variable & Supply Chain issues (X) \\
\hline Multiple R-value & 0.179 \\
\hline R-Square Value & 0.032 \\
\hline Adjusted R-Square Value & 0.021 \\
\hline F-value & 2.807 \\
\hline p-value & $<0.098$ \\
\hline
\end{tabular}

Table 3 shows the results of regression analysis, $R^{2}=0.032$ and Adjusted $R^{2}=0.021$, which reveals that the independent variable, supply chain issues describes $3.2 \%$ of the variability of the dependent variable, organized retailer performance in a given population. Adjusted $\mathrm{R}^{2}$ value also an estimate of the effect size which is at 0.021 i.e. $2.1 \%$ is indicative of a small 
effect size to Cohen's (1988) classification [16]. The regression model is statistically insignificant with $\mathrm{p}$-value $=0.098$ at $5 \%$ significance level, this indicates that overall model is not significant to predict the dependent variable.

Table 4. Regression analysis-coefficients

\begin{tabular}{|c|c|c|c|}
\hline \multicolumn{2}{|c|}{ Model } & (Constant) & Total SCI \\
\hline \multirow{2}{*}{ Unstandardized Coefficients } & B & 29.914 & -0.240 \\
\cline { 2 - 4 } & Standard Error & 3.865 & 0.143 \\
\hline Standardized Coefficients & Beta & ----- & -0.179 \\
\hline \multicolumn{2}{|c|}{ Significance value } & 0.000 & 0.098 \\
\hline
\end{tabular}

Regression analysis coefficients are shown in table 4 and regression model can be fit using the above results. The linear regression model is $\mathrm{Y}=29.91+3.865 \mathrm{X}$ or Organized retailer performance $=29.914+3.865$ Supply chain issues). $F$-value is 2.807 and significance value is 0.098 which is greater than 0.05 , at a significance level of $5 \%$. Hence, it indicates that there is lack of linear relationship between supply chain issues and organized retailer performance.

\section{Conclusions}

The statistical analysis was performed in the study to determine the effect of various factors such as farmer's demographics and supply chain issues influencing performance of organized retailer. First hypothesis test results indicate that farmer's demographics have no influence on organized retailer performance. Second hypothesis analyse the impact of supply chain problems faced by famers and its influence on retailer performance. Linear regression analysis was used to test the linear relation between the variables. Results of the study show the lack of linear relationship and hence supply chain issues have no influence on organized retailer performance. The outcome of the study implies that independent variables stated have no control over the retailer's performance. Management has to look in to other aspects which imbalance the supply chain leading to not meeting the customer requirements at right time. This study may help the retailers to understand the supplier problems and to monitor the supplier performance to control variables like delivery time, wastage, quality, capacity utilization.

\section{References}

1. S. Negi and N. Anand, "Issues and challenges in the supply chain of fruits and vegetable sector in India-A Review", International Journal of Managing Value and Supply Chains (IJMVSC) Vol. 6, No. 2, June 2015.

2. ASSOCHAM "Horticulture Sector in India - State Level Experience", The Associated Chambers of Commerce and Industry of India, New Delhi, 2013.

3. S Negi and N Anand, "Cold Chain: A Weak Link in the Fruits and Vegetables Supply Chain in India", The IUP Journal of Supply Chain Management, Vol. 52 XII, No. 1, 2015.

4. Piali Halder and Simayan Pati, "A need for paradigm shift to improve supply Chain management of fruits \& vegetables in India", Asian Journal of Agriculture and Rural Development, 1(1), 1-20, 2012.

5. Adi Djoko Guritno, Rika Fujianti, Dinovita Kusumasari, “Assessment of the Supply Chain Factors and Classification of Inventory Management in Suppliers' Level of Fresh Vegetables", Agriculture and Agricultural Science Procedia 351 - 55, 2015. 
6. Manish Shukla, Sanjay Jharkharia, "Agri-fresh produce supply chain management: a state-of-the art literature review", International Journal of Operations \& Production Management, Vol. 33 Issue: 2, pp.114-158, 2013.

7. Modi P, Mishra D, Gulati H and Murugesan K "Uttarakhand State Cooperative Federation: Can it Help The Horticulture Farmers?", Vision-The Journal of Business Perspective, Vol. 13, No. 2, pp. 53-61, 2009.

8. Viswanadham N "Can India be the Food Basket for the World?", Working Paper Series, Indian School of Business, Hyderabad, India, 2007.

9. M. Balaji, K. Arshinder, "Modeling the causes of food wastage in Indian perishable food supply chain” Resources, Conservation and Recycling 114, 153-167, 2016.

10. L. Wanxian, L. Xinmei, and W. Weiwu, "Demographic Effects of Work Values and Their Management Implications", Journal of Business Ethics, 2008, 81:875-885, 2007.

11. Sunil Bhardwaj and Indrani Palaparthy, "Factors Influencing Indian Supply Chains of Fruits and Vegetables: A Literature Review", The Icfai University Journal of Supply Chain Management, Vol. V, No. 3, 2008.

12. Raghuram Naga Venkata J \& Ravilochanan P, "The Role of Supply Chain Management on Organized and Unorganized Grocery Retailers-A Review on Indian Perspective”, Asian Social Science; Vol. 10, No. 22; 2014.

13. Ruoqi Geng, S. Afshin Mansouri, Emel Aktas, "The relationship between green supply chain management and performance: A meta-analysis of empirical evidences in Asian emerging economies" Int. J. Production Economics 183, 245-258, 2017.

14. N. R. Kenneth, "Quantitative research methods in educational planning" UNESCO International Institute for Educational Planning, 2005.

15. Israel, Glenn D., "Sampling The Evidence Of Extension Program Impact. Program Evaluation and Organizational Development", IFAS,University of Florida. PEOD-5. 1992.

16. Kotrlik, Williams, \& Jabor, "Reporting and Interpreting Effect Size in Quantitative Agricultural Education Research", Journal of Agricultural Education Volume 52, Number 1, pp. 132-142, 2011.

17. C.R. Kothari, "A Text Book On Research Methodology-Methods and Techniques", 2004. 